\title{
A study of Negative Transfer in Students' Vocabulary learning
}

\author{
Yuehui Niu ${ }^{1, a}$, Xiaohui Wang ${ }^{2, b}$ \\ ${ }^{1}$ North China Electric Power University, Changping District, Beijing \\ ${ }^{2}$ North China Electric Power University, Changping District, Beijing \\ a969869066@qq.com, ${ }^{b} 762816014 @ q q . c o m$
}

Keywords: Negative transfer of mother tongue; Vocabulary error

\begin{abstract}
Language transfer has been a controversial topic in the field of second language acquisition. In recent years, scholars from home and abroad have studied the language transfer from different perspectives. They believe that language transfer is a complex cognitive process. Transfer is divided into positive and negative transfer, positive transfer is similar between native language and the target language while negative transfer refers to the interference between L1 and L2. Since the negative transfer of mother tongue on vocabulary can not be avoided, so this paper focuses on the types of lexical errors caused by negative transfer so as to reduce the influence of negative transfer, it also puts forward some suggestions to improve the negative transfer effect on learner's vocabulary, so as to improve the students’ English level and learning efficiency.
\end{abstract}

\section{Introduction}

In recent years, linguists are becoming more and more interested in the relationship between mother tongue and second language acquisition. Since 1950s, people have begun to study the transfer of native language in second language acquisition. The phenomenon of language transfer refers to the fact that learners study a foreign language which will be influenced by their mother tongue, and the degree of impact is based on their mastering the pronunciation, vocabulary and grammar. Therefore, in learning a foreign language, we should pay attention to the influence of mother tongue on second language acquisition. "Transfer" is a psychological term, it refers to the process in which learners transfer the knowledge or experience he has acquired to the new knowledge he is learning.

Multilingual researchers believe that "Language is word." Wilkins argues that "Without grammar, only a small amount of information can be transmitted; without words, no information can be transmitted." Mac Carthy also pointed out that"No matter how good the grammar of a learner's second language is, no matter how standard the pronunciation is, if you don't have enough vocabulary, you can't communicate successfully in a second language.” As a result, vocabulary is the foundation of language construction, and vocabulary learning is also the key to language learning. Therefore, it is very important to improve the quality of English teaching, to help the students develop good "English thinking" habits, and avoid the negative transfer of mother tongue effectively in the process of English vocabulary learning. This paper focuses on the types of lexical errors caused by negative transfer, and puts forward some suggestions to help teachers find a way to promote the positive transfer of mother tongue and reduce the impact on negative transfer.

\section{The negative transfer on vocabulary}

\subsection{The function words}

Conjunctions, preposition, articles and pronouns consist of the "function words " or "grammatical words", these words are in a small number, stable and few words can be added in it. The first type is "prepositions", both English and Chinese have prepositions, in English it is more 
complicated and difficult for students to learn. In Chinese, there are 30 prepositions but there are 285 prepositions used in English. Prepositions appear in students' writing and oral expressions, but in Chinese they are usually omitted by us. For example:

(1) I live in Beijing several years.

(2) When I feel relaxed I look back those months.

(3) She got a divorce with her husband.

In the first sentence, there is no need to add "for" to express that you have lived in there for a long time. In the second sentence, when we say "huì xiăng qǔ nà xiē nián" we do not use the proposition "on", for it is the Chinglish expression in English-speaking country. In the third sentence, the negative transfer is caused by students seeking help from their mother tongue. "hé shuí lí hūn", in Chinese literally we say "get a divorce with somebody", but in English the correct form is " get a divorce from her husband."

The second type is "articles", there are three forms of articles in English: definite, indefinite and zero articles. Chinese students find it hard to use the three forms of articles partly because there are an uncountable number of rules. Some Chinese students will omit or insert articles which are necessary or unnecessary in some sentences. For example:

(1) I like playing piano.

(2) If you like our product we will give you at $90 \%$ discount.

In the first sentence, as we all know when someone plays the piano, we always add the word "the". In the second sentence, according to the English grammar, the correct form should be "at a $90 \%$ discount". And in the following sentences unnecessary articles are used:

(3) He finished the work several hours ago.

(4) My friend Lisa took the fancy to that boy.

The third type is pronouns. English pronouns consist of eight forms, there are possessive pronouns, reflexive pronouns, interrogative pronouns, indefinite pronouns, comprising personal pronouns, reciprocal pronouns, demonstrative pronouns and relative pronouns. Compared with Chinese, English use pronouns more often in the writing or oral expressions. Chinese students often omit pronouns in some improper places. So they often speak incorrect sentences in following forms:

(1) He knows that he deeply love father.

(2) He usually comes into the hospital with sadness on face.

In the first sentence, the Chinese students omit the pronoun "his", for they can get the message that it refers to "tā dè fù qīn", but for English native speakers they are more likely to add the word "his". In the second sentence, the Chinese students omit the pronoun "his" for they already know that it refers to "tā liăn shàng dài zhè bēi shāng", while in English speaking country, they prefer "with sadness on his face".

\subsection{The content words}

In English, the number of nouns, verbs, adjectives and adverbs make up the large part of vocabulary. They are content words of a language and new words can be add to them. There are some errors that students might encounter in their speaking.

The first type is nouns, nouns used in a language are label of the objects they stand for. Both English and Chinese share the similarities in the properties of nouns. Nouns have three grammatical categories to describe nouns properties. There are gender number and case. Among the three properties, the most difficult one for English learners is number. Nouns consist of countable nouns and uncountable nouns. Countable nouns have singular and plural forms and uncountable nouns only have singular form. English learner may get confused in this part, for it is difficult and complicated. Uncountable nouns such as chicken, news and housework are typical. In the Chinese concept some words can be counted, such as "yì tiáo xīn wěn". Another misconception is the plural form of a word. According to English grammatical rules, learners should add "-s" or "-es" at the end of a word, but there are also some words that do not need this change --- adding "-s" or "-es", such as foot-feet. 
The second type is adjectives. Adjectives consist of gradable and non-gradable. In this part we mainly discuss the most important and difficult --- gradable. "Gradable" has two forms, i.e. comparative and superlative degree. In our mother tongue when we express something is good in quality, we usually add "gèng" or "zuì" before an adjective, while in English we have two ways to express it. Firstly, we can add "more" or "most" before an adjective. Secondly, we can add "-er" or "-est" at the end of an adjective. For example, "bigger" "biggest". Some non-gradable adjectives themselves are contain comparative or superlative degree such as "perfect" and "excellent", so when students translate the following sentences into English they will make a mistake --- "wǒ shì xuē xiào zuì hăo dè lăo shî" and "bǐ qǔ quán bān tóng xué tā gèng yōu xìu", consequently, they will express the sentence as "the toppest teacher in this school" and "he is the most excellent student in his class". These two sentences should be corrected as "I remain to be the top teacher in this school" and "He always outdoes his classmate."

The third type is verbs. Verbs consist of transitive verbs and intransitive verbs. Some English learners can not distinguish between them. A transitive verb requires a direct object, while an intransitive verb requires no direct object. As we all know, both Chinese and English have transitive and intransitive verbs. But some English verbs are often used as transitive verbs in Chinese when the meaning of it is almost the same. So student may be confused when they meet these words. For example:

(1) As an adult, he still depends his father.

(2) She married with a doctor.

In the first sentence, "depend" is an intransitive verb, while in our mother tongue "yī lài" is a transitive verb. In the second sentence, "marry" is a transitive verb while in our mother tongue "jié hūn" is an intransitive verb. Therefore, the two sentences should be expressed as "As an adult, he still depends on his father." "She got married with a doctor."

\section{Implications for teachers and students}

\subsection{Ensure the correctness of vocabulary input}

English and Chinese are not completely equivalent, in most cases, we look through English-Chinese dictionaries, which plays a negative role in understanding the actual meaning of the words in certain context. Learners who frequently use English-Chinese dictionaries will increase the negative transfer of mother tongue. Teachers should guide their students to make constrastive analysis between Chinese and English in the process of teaching, so as to help students to enhance their English awareness and reduce the negative transfer of their mother tongue.

\subsection{Make clear classification of word class}

English belongs to the inflectional langauge, a number of English words have perfix, infix or suffix. The change of perfix will influnence the meaning of a word, and the change of a suffix will influence the part of speech of a word. Generally speaking, the part of speech of Chinese is not as obvious as English. Some students can not distinguish the part of speech of English word and confuse about the functions and usage of the words, which will lead students pay more attention to the meaning of the words and ignore its part of speech. Teachers should pay more attention to the classification of word class teaching.

\subsection{Strengthen the contrast between English and Chinese}

In the process of second language learning, it is improtant to find the differences and similarity by using contrastive analysis. The grammatical system of English is different from Chinese, both in syntax rules and language structure. Comparing the differences of the two languages is helpful for students to recognize and reduce the negative transfer of mother tongue. Under the guidance of the teacher's instruction, students should also sum up what teachers have taught through autonomous learning. 


\section{Conclusion}

Second language acquisition is a complex process that involves many factors. Negative transfer of words is inevitable in the process of second language acquisition, but teachers and students can reduce the negative transfer of vocabulary through effective ways to achieve the purpose of learning.

\section{References}

[1] Allen, V.F. Techiniques in Teaching Vocabulary[M]. Oxford: Oxford University Press, 2002

[2] Corder, D. Error Analysis and Interlanguage[M]. Oxford: Oxford University Press,1984

[3] Xiaoning WANG.Negative Transfer of Chinese in English Learners' Lexical Learning: A Markedness Theory Perspective[J].Studies in Literature and Language.2013,Vol.7(No.3): 6-11.

[4] Marianna M. Walker. Transfer of lexical information in adults with reading disorders[J]. Perceptual and Motor Skills.2001,Vol.93(No.1): 257-267.

[5] Odlin, T. Language Transfer [M]. Cambridge: Cambridge University Press, 2009 